\title{
KONSEP GURU EFEKTIF DALAM PEMBELAJARAN PENDIDIKAN AGAMA ISLAM
}

\begin{abstract}
Oleh: Musyaffa Rafiqie

Email:

fiq.dewi@gmail.com

Effective teachers will always look for better ways in teaching. There are four components that need to be considered for effective teachers. The four components are the first teacher having mastery of knowledge about teaching materials and teaching materials tanght by both teachers having critical thinking skills and able to solve the problems that exist in the learning of the three teachers has the ability of knowledge about the characteristics of students and master the learning methods. And the four teachers have skills in teaching and can communicate well with students. Thus, the purpose of discussion from this research report is to describe the effective teacher.
\end{abstract}

Universitas Ibrahimy, Situbondo
Keywords: Effective, Teacher, PAI.

\section{PENDAHULUAN}

Dalam Kamus Umum Bahasa Indonesia Balai Pustaka dikatakan bahwa arti kata efektif adalah ada pengaruhnya, manjur dan mujarab ${ }^{1}$. Kata efektif berasal dari bahasa Inggris yang artinya tepat atau berhasil. Dengan demikian, kata efektif disimpulkan adalah sesuatu yang menghasilkan ketercapaian dan keberhasilan dalam mencapai tujuan.

Efektif dalam pembelajaran apabila peserta didik yang ikut dalam pembelajaran mampu menguasai materi ajar dan menghasilkan hasil belajar sesuai kompetensi yang telah ditetapkan, dalam kurun waktu tertentu kompetensi belajar dapat dicapai dengan baik atau tuntas. ${ }^{2}$

Guru efektif dalam pembelajaran menurut NCTE dalam Slavin dalam Quality Concerns in Secondary Teacher Education, Guru adalah elemen terpenting dan utama serta bertanggung jawab atas pelaksanaan proses pembelajaran. ${ }^{3}$ Selanjutnya dikatakan bahwa seorang guru yang efektif akan selalu mencari cara yang lebih baik dalam mengajar. Artinya seorang guru yang efektif apabila disaat proses pembelajaran sedang berlangsung dan kondisi kelas atau suasana kelas riuh gemuruh atau berisik maka guru efektif akan berusaha mencari pendekatan yang berbeda, yakni Guru akan berhenti bicara, kemudian melakukan kontak mata untuk menenangkan kelas, serta mendekati peserta didik atau tepat berada diantara peserta didik yang sedang ribut atau gaduh hingga peserta didik berhenti ribut atau gaduh. Hal tersebut dilakukan oleh Guru dalam rangka memberikan contoh dan pengaruh bimbingan pada peserta didik. ${ }^{4}$ Dengan demikian, Guru secara terus menerus atau berkesinambungan memberikan bimbingan dan motivasi kepada peserta didiknya.

Guru dalam melaksanakan tugasnya akan terus mendapat kendala atau problem atau permasalahan dalam kegiatan pembelajaran,

\footnotetext{
3 R.E Slavin, Educational Psychology: Theory and Practices (New Jersey: Pearson, 2009)

${ }_{4}^{4}$ K.T. Henson dan B.E. Eller, Educational Psychology for Effective Teaching (Belmont: Wadsworth Publishing Company, 1999),

1 Poerwadarminta, Kamus Umum Bahasa Indonesia (Jakarta: Balai Pustaka, 1979), 47.

${ }^{2}$ Hamzah B. Uno dan Nurdin Mohamad, Belajar 2011 dengan Pendekatan Pailkem: Pembelajaran Aktif, Inovatif, Lingkungan, Kreatif, Efektif, Menarik (Jakarta: Bumi Aksara, t.t), 27.
} 
dikatakan bahwa guru akan terus menghadapi tantangan dalam proses pembelajaran. ${ }^{5}$

Pembelajaran Pendidikan Agama Islam adalah Pendidikan Agama Islam adalah upaya sadar dan terencana dalam menyiapkan peserta didik untuk mengenal, memahami, menghayati hingga mengimani,bertakwa, dan berakhlak mulia dalam mengamalkan ajaran agama Islam dari sumber utamanya kitab suci al-Qur'an dan hadis, melalui kegiatan bimbingan, pengajaran, latihan, serta penggunaan pengalaman. Dibarengi tuntutan untuk menghormati penganut agama lain dalam masyarakat hingga terwujudnya kesatuan dan persatuan bangsa. ${ }^{6}$

Guru efektif dalam pembelajaran Pendidikan Agama Islam yang dimaksud dalam penelitian ini adalah teori Slavin adalah Guru efektif yang memiliki kemampuan pertama, guru memiliki penguasaan pengetahuan tentang materi ajar, atau bahan ajar yang diajarkan. Materi ajar atau bahan ajar yang dimaksud adalah merupakan materi pelajaran yang disusun secara sistematis, yang nantinya digunakan oleh tenaga pendidik/Guru atau peserta didik dalam kegiatan proses belajar dan mengajar atau proses pembelajaran. Kedua, guru memiliki kemampuan berpikir kritis dan mampu memecahkan permasalahan yang ada dalam pembelajaran. Ketiga, guru memiliki kemampuan pengetahuan tentang karakteristik peserta didik dan menguasai metode pembelajaran. Dan keempat, guru memiliki keterampilan dalam pengajaran serta dapat berkomunikasi baik dengan peserta didik. ${ }^{7}$

\section{PEMBAHASAN}

Berikut ini dideskripsikan teori Slavin tentang guru efektif dalam bukunya yang berjudul Educational Psychology: Theory and Practices, adalah sebagai berikut:

\footnotetext{
${ }^{5}$ Elliot, S. N., Kratochwill, T.R, Littlefield, J., \& Travers, J.F. Educational Psychology Effective Teaching Effective Learning (Singapore: McGraw Hill Book, 1999), 35.

${ }^{6}$ Depdiknas, Kurikulum 2004 Standar Kompetensi Pendidikan Agama Islam Sekolah Menengah Atas dan Madrasab Aliyah (Jakarta: Pusat Kurikulum Balitbang Depdiknas, 2004), 1. ${ }^{7}$ Depdiknas, Kurikulum 2004 Standar Kompetensi Pendidikan Agama Islam Sekolah Menengah Atas dan Madrasah Aliyah (Jakarta: Pusat Kurikulum Balitbang Depdiknas, 2004), 3.
}

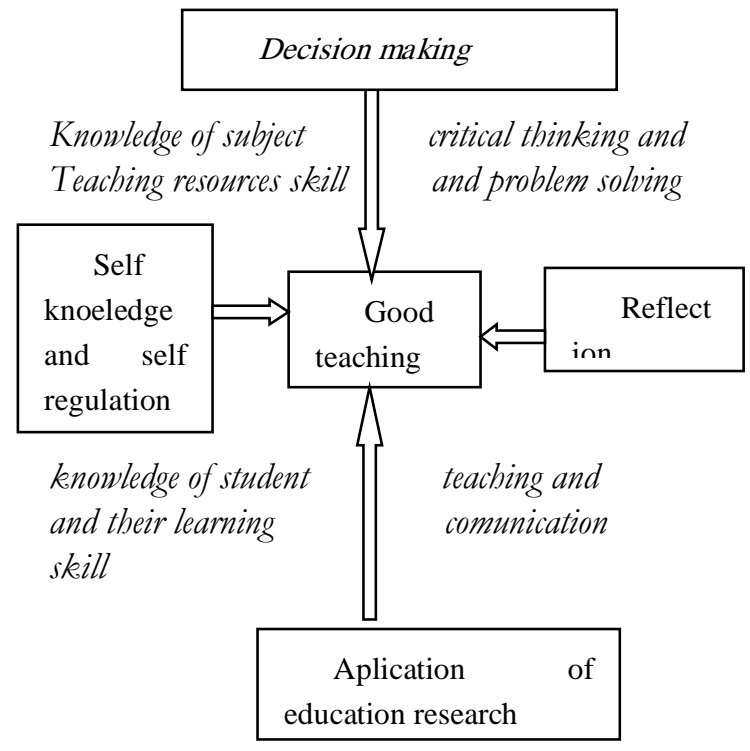

Gambar 1. Komponen guru yang baik

\section{Guru Memiliki Penguasaan Pengetahuan Tentang Materi dan Bahan Ajar}

Secara harfiah penguasaan berasal dari kata kuasa, yakni memiliki kemampuan atau kesanggupan dalam berbuat atau bertindak. ${ }^{8}$ Ditinjau dari sisi pendidikan maka yang dimaksud penguasaan adalah suatu proses kemampuan, kecakapan, dan keterampilan yang dimiliki oleh guru. ${ }^{9}$ Dengan demikian penguasaan merupakan suatu kemampuan untuk berbuat dan bertidak serta menjalankan kecakapan dan keterampilan yang dimilikinya dalam rangka melaksanakan tugas yang menjadi tanggung jawabnya.

Bahan ajar ialah seperangkat materi pembelajaran yg disusun secara sistematis, menampilkan sosok utuh dari kompetensi yang akan dikuasai siswa dalam kegiatan pembelajaran. ${ }^{10}$ Berangkat dari pengertian di atas, maka dapat dipetakan bahwa yang dimaksud dengan Bahan ajar adalah segala bentuk bahan baik berupa secara materi ataupun material yang digunakan untuk membantu guru dalam melaksanakan kegiatan belajar mengajar di kelas. Bahan yang dimaksud bisa berupa bahan tertulis maupun bahan tidak tertulis.

\footnotetext{
8 Depdiknas, Kurikulum 2004 Standar Kompetensi Pendidikan Agama Islam Sekolah Menengah Atas dan Madrasah Aliyah (Jakarta: Pusat Kurikulum Balitbang Depdiknas, 2004), 1.

9 Nana Sudjana, Penilaian Hasil Proses Belajar Mengajar (Bandung: Rosda Karya, 2009), 12.

${ }^{10}$ Chomsin S Widodo and Jasmadi, Panduan Menyusun Baban Ajar Berbasis Kompetensi (Jakarta: Elex Media Komputindo, 2008), 21.
} 
Perlu dibedakan antara bahan ajar dan sumber belajar. Sumber belajar adalah segala sesuatu atau daya yang dapat dimanfaatkan oleh guru,segala sesuatu yang dapat memberikan kemudahan belajar, yang darinya diperoleh berbagai informasi, pengetahuan, pengalaman, dan keterampilan yang diperlukan untuk pembelajaran baik secara terpisah maupun dalam bentuk gabungan, untuk kepentingan belajar mengajar dengan tujuan meningkatkan efektivitas dan efisiensi tujuan pembelajaran. ${ }^{11}$ Sedangkan bahan ajar adalah materi yang tertuang atau segala hal yang dapat diambil manfaat dari sumber belajar.

Bahan ajar yang inovatif dan menarik perlu dikembangkan oleh guru. Sebab tujuan dari pengembangan bahan ajar di antaranya ialah menyediakan bahan ajar yang sesuai dengan tuntutan kurikulum dengan tujuan kebutuhan siswa, yakni bahan ajar yang sesuai dengan karakteristik dan setting atau lingkungan sosial siswa. Membantu siswa dalam memperoleh alternatif bahan ajar di samping makalah-makalah teks yang terkadang sulit diperoleh. Juga memudahkan guru dalam melaksanakan pembelajaran, sekaligus sebagai pedoman dalam mengarahkan aktivitasnya dalam proses pembelajaran. Selain itu pengembangan bahan ajar juga ditujukan sebagai alat ukur atau evaluasi dalam suatu proses pembelajaran sehingga kemampuan dan pemahaman siswa dapat diketahui. Bahan ajar disini juga dapat dijadikan sebagai pengukuran bagi peserta didik dalam proses pembelajaran , dengan cara mengidentifikasi pemahaman siswa dari latihanlatihan yang ada di bahan ajar.

Penguasaan materi ajar dalam pembelajaran pendidikan agama islam seorang guru dituntut untuk mengetahui, menguasai dan memahami bahan ajar dan materi ajar dengan baik. Agar bahan ajar dan materi ajar diketahui, dikuasai dan dipahami maka bahan dan materi ajar tersebut perlu diorganisasikan secara sistematis dan logis, maka indikatornya bahan dan materi ajar tersebut agar mampu menghasilkan kompetensi yang sudah ditetapkan dalam silabus maka perlu memperhatikan yakni: a) harus

11 Arief Sadiman, Pendayagunaan Teknologi Informasi dan Komunikasi untuk Pembelajaran, (Jakarta: Raja Grafindo, 2004), 23.

12 E. Mulyasa, Menjadi Guru Profesional, Menciptakan PembelajaranKreatif dan Menyenangkan, (Bandung: Remaja Rosda Karya, 2007), 15. mampu menghubungkan isi, bahan dan materi ajar dengan apa yang telah diketahui peserta didik, sebab akan memberikan pengalaman belajar; b) mampu menghubungkan dan mengaitkan isi bahan dan materi ajar dengan perkembangan ilmu pengetahuan dan tekhnologi; c) mampu mengambil manfaat dari hasil proses pembelajaran; d) pemilihan buku referensi dan buku bacaan yang lain, di samping buku bacaan yang didapat dari sekolah; e) adanya rencana pembelajaran (RPP), yang membahas tentang pokok bahasan. Hal yang lebih penting lagi kemauan dan semangat untuk mengikuti pembelajaran dan mengerjakan tugas yang dibebankan atau untuk membahas pokok bahasan tertentu perlu diundang guru yang professional untuk mendapatkan gambaran dan pengetahuan tentang bahan dan materi ajar. ${ }^{12}$

\section{Kompetensi Berpikir Kritis dan Problem Solving Guru}

Eliana Crespo mengatakan bahwa critical thinking adalah istilah umum yang diberikan untuk berbagai keterampian kognitif dan intelektual membutuhkan:

1. mengidentifikasi, menganalisa, dan mengevaluasi secara efektif.

2. menemukan dan mengatasi prasangka.

3. merumuskan dan menyajikan alasan-alasan yang meyakinkan untuk mendukung kesimpulan.

4. membuat pilihan yang cerdas dan beralasan tentang apa yang harus dipercaya dan yang harus dilakukan. ${ }^{13}$

Selanjutnya dikatakan oleh H.A.R. Tilaar bahwa berpikir kritis merupakan suatu yang penting di dalam pendidikan hal ini disebabkan, karena beberapa pertimbangan antara lain ialah: ${ }^{14}$ 1. Mengembangkan berpikir kritis di dalam pendidikan berarti kita memberikan penghargaan kepada peserta didik sebagai pribadi (respect a person). Hal ini akan memberikan kesempatan kepada perkembangan pribadi peserta didik sepenuhnya karena mereka merasa diberikan

13 Djuwairiyah and Moh. Nawafil, "Urgensi Pengelolaan Kelas; Suatu Analisis Filosofis Dan Pemahaman Dasar Bagi Kalangan Pendidik Di Pesantren," Edupedia: Jurnal Studi Pendidikan Dan Pedagogi Islam 5, no. 2 (2021): 27-36.

14 H.A.R. Tilaar, Pedagogik Teoritis Untuk Indonesia (Jakarta: Kompas, 2015), 54. 
kesempatan dan dihormati akan hak-haknya dalam perkembangan pribadinya.

2. Berpikir kritis merupakan tujuan yang ideal di dalam pendidikan karena mempersiapkan peserta didik untuk kehidupan kedewasaannya.

3. Perkembangan berpikir kritis dalam proses pendidikan merupakan suatu cita-cita tradisional seperti apa yang ingin dicapai melalui pelajaran ilmu eksata dan ilmu sosial lainnya termasuk ilmu pendidikan agama islam. yang secara tradisional dianggap dapat mengembangkan berpikir kritis.

4. Berpikir kritis merupakan suatu hal yang sangat dibutuhkan di dalam kehidupan demokratis. Demokrasi hanya dapat berkembang apabila warga negaranya dapat berpikir kritis di dalam masalah-masalah politik, sosial, dan ekonomi. ${ }^{15}$

Ahli lain berpendapat tentang berpikir kritis yang dikemukakan oleh Johnson E, yang merupakan pelopor pembelajaran Contextual Teaching Learning, bahwa peserta didik yang memiliki kemampuan berpikir kritis yang memadai memiliki kemungkinan besar untuk dapat mempelajari masalah secara sistematis, menghadapi berjuta tantangan dengan cara terorganisasi, merumuskan pertanyaan inovatif, dan merancang penyelesaian yang dipandang relatif baru. ${ }^{16}$

Dari pendapat ketiga akhli tentang berpikir kritis dapat disimpulkan suatu kemampuan individu atau guru dalam menerapkan atau mengunakan kognitifnya untuk mengidentifikasi, menganalisa, merumuskan, menyajikan dan meyakinkan alasannya guna mendukung kesimpulannya yang dimplementasikan dengan membuat pilihan yang cerdas dan beralasan tentang apa yang harus dipercaya dan dilakukan. Sebagai contoh dalam pendidikan dalam pengembangan berpikir kritis, seorang peserta didik akan mendapatkan respect a person sebab seorang peserta didik merasa diberikan kesempatan dan dihormati akan hakhaknya dalam perkembangan pribadinya.

Berpikir kritis sangat dibutuhkan oleh peserta didik maupun guru, hal ini disebabkan

15 H.A.R. Tilaar, Pedagogik Teoritis Untuk Indonesia (Jakarta: Kompas, 2015), 56.

16 Elaine B. Johnson, Contextual Teaching and Learning (California: Corwin Press, 2002), 18. untuk perkembangan dalam berkehidupan berdomokrasi, yang di ajarkan tentang pokok bahsan Al Qur'an dan Hadist. Seerti pada pokok bahsan Al-Qur'an dan Hadist dalam silabus kelas VII yakni QS. Al-Mujahadah 58:11 dan Q.S Ar Rahman 55:33 beserta hadistnya terkait tentang menuntut ilmu.

\section{Kompetensi Guru tentang Karakteristik Siswa dan Metode Pembelajaran}

Mengenal karakteristik peserta didik untuk membantu guru dalam menghantarkan keberhasilan belajar peserta didik. Untuk memahami karakteristik peserta didik membutuhkan keseriusan dan kesungguhan, hal ini disebabkan karena karakter peserta didik merupakan komponen penting dalam kesuksesan pembelajaran dan hasil belajar. Bagaimana mengkondisikan peserta didik sesuai dengan karakteristik masing-masing dalam pembelajaran. Setiap peserta didik memiliki karakteristik yang berupa bakat, minat, sikap, motivasi belajar, serta gaya belajar. Setiap peserta didik memiliki karakteristik yang berbeda-beda. Perbedaan karakteristik peserta didik sebagai hasil dari interaksi antara pembawaan (genetik) dengan lingkungan sosialnya, sehingga menentukan pola aktivitasnya dalam mewujudkan harapan dan meraih cita-cita peserta didik. Oleh karena itu, upaya memahami perkembangan peserta didik harus dihubungkan atau disesuaikan dengan karakteristik peserta didik itu sendiri.

Dalam memahami karakteristik peserta didik seorang guru harus mampu memahami karakteristik peserta didik baik secara individu maupun secara kelompok. Ada Empat hal pokok faktor dominan dari karakteristik peserta didik yang harus diketahui dan dipahami oleh guru yaitu :pertama. Kemampuan dasar peserta didik seperti kemampuan kognitif atau intelektual, kedua. Latar belakang kultural lokal, status sosial, status ekonomi, agama dan lain sebagainya, ketiga Perbedaan kepribadian seperti sikap, perasaan, minat, dan lain sebagainya, keempat cita-cita, pandangan ke depan, keyakinan diri, daya tahan,dan lain sebagainya ${ }^{17}$

Tujuan identifikasi karakteristik peserta didik adalah sebagai berikut : a) memperoleh informasi yang lengkap dan akurat berkenaan

17 Meriyati, Memahami Karakteristik Peserta Didike (Lampung: IAIN Raden lntan Lampung Press, 2015), 63. 
dengan kemampuan serta karakteristik awal peserta didik sebelum mengikuti kegiatan pembelajaran; b) menyeleksi tuntutan, bakat, minat, kemampuan, serta kecenderungan peserta didik berkaitan dengan pemilihan program-dalam pembelajaran yang akan diikuti oleh peserta didik; c) menentukan desain program pembelajaran dan atau pelatihan tertentu yang perlu dikembangkan sesuai dengan kemampuan awal peserta didik. Seorang guru jika ingin mengetahui karakteristik kemampuan awal dari peserta didik, dapat dilakukan dengan pemberian tes (pre-test). Tes yang diberikan dapat berkaitan dengan materi ajar sesuai dengan kompetensi inti dan kompetensi dasar yang ada pada panduan kurikulum. Selain itu pendidik dapat melakukan wawancara, observasi dan memberikan kuesioner kepada peserta didik, guru yang mengetahui kemampuan peserta didik atau calon peserta didik, serta guru yang biasa mengampu pelajaran tersebut. Teknik untuk mengidentifikasi karakteristik siswa adalah dengan menggunakan kuesioner, interview, observasi dan tes latar belakang sisw. Guru perlu mempertimbangkan dalam mempersiapkan materi yang akan disajikan, di antaranya yaitu faktor akademis dan factor sosial: a) faktor akademis yang akan dikaji meliputi jumlah peserta didik yang dihadapi di dalam kelas, rasio guru dan peserta didik menentukan kesuksesan belajar, indeks prestasi, tingkat inteligensi siswa juga tidak kalah penting; b) faktor sosial faktor kematangan dan ekonomi siswa sangat berpengaruh pada faktor sosial peserta didik.

Aspek-aspek yang diungkap dalam kegiatan ini bisa berupa bakat, motivasi belajar, gaya belajar kemampuan berfikir, minat dan lain sebagainya. Faktor sosial ini dalam hubungannya dengan masyarakat serta berbagai kegiatan lainnya yang mempengaruhi cara bersosialisasi dengan orang lain. ${ }^{18}$

Dengan demikian, mengetahui dan memahami karakteristik peserta didik sangat penting dan urgen untuk diketahui dan dipahami oleh guru. Untuk mengetahui dan memahami karakteristik peserta didik dapat melalui kegiatan pemberian tes (pre-test). Pemberian pre-test dapat dilakukan disaat awal pembelajaran dan

\footnotetext{
18 Moh. Nawafil and Junaidi Junaidi, "Revitalisasi Paradigma Baru Dunia Pembelajaran Yang Membebaskan," Jurnal Pendidikan Islam Indonesia 4, no. 2 (April 15, 2020): 215-25, doi:10.35316/jpii.v4i2.193.

${ }^{19}$ Meriyati, Memahami Karakteristik Peserta Didik (Lampung: IAIN Raden lntan Lampung Press, 2015), 57.
}

post test diberikan disaat akhir dalam pembelajaran.

\section{Keterampilan Guru dan Kecakapan Komunikasi terhadap Peserta Didik}

Kegitan pembelajaran di kelas membutuhkan komunikasi tersendiri, di mana antara guru dan peserta didik bertukar pikiran, dan mengembangkan ide pengetahuan, keterampilan, nilai akhlak, dan sikap melalui komunikasi edukatif.

Agar komunikasi memiliki arti dan makna sebagai edukatif, diantaranya dibutuhkan komunikasi. Komunikasi dapat didefinisikan sebagai transmisi pesan yang melibatkan pemahaman bersama antara konteks di mana komunikasi berlangsung antara guru dan peserta didik. ${ }^{19}$ Komunikasi antara guru dan peserta didik sangatlah penting dalam memuluskan rencana pembelajaran dan tugas belajar peserta didik. Komunikasi yang efektif dan interaktif dapat mencapai tujuan pembelajaran secara mudah.

Selain itu, keterampilan komunikasi guru sangat penting bagi seorang guru dalam penyampaian pendidikan kepada peserta didik. Keterampilan komunikasi meliputi: mendengarkan, berbicara, membaca serta menulis. ${ }^{20}$ Mendengarkan tersebut ialah dapat menerima segala keluh kesah atau kendala pembelajaran yang diutarakan oleh peserta didik. Berbicara ialah dapat menyampaikan pesan yang bernilai kepada peserta didik. Membaca maksudnya ialah dapat memahami kesempata dan persoalan yang butuh diberikan solusi secepatnya. Menulis ialah merangkai materi ajar dengan sebaik dan seinovatif mungkin sehingga siswa terangsang dalam belajar.

Untuk pengajaran yang efektif, seorang guru harus terampil dalam bidang mendengarkan, berbicara, membaca serta menulis. Guru dengan berkomunikasi yang baik selalu membuat segala sesuatunya lebih mudah dan dapat dimengerti oleh peserta didik. Komunikasi yang efektif sangat penting bagi seorang guru dalam mentransmisikan pengetahuan, pendidikan, manajemen kelas dan interaksi dengan peserta didik di kelas. ${ }^{21}$

\footnotetext{
${ }^{20}$ Kementerian Pendidikan Nasional RI, Panduan Guru Mata Pelajaran Pendidikan Agama Islam: Pendidkan Karakter Terintegrasi Dalam Pemeblajaran Di Sekolah Menengah Pertama (Jakarta: Kemendiknas, 2010), 16.

21 Andi Syukri Syamsuri, Pendidikan Guru Dan Pembelajaran (Makassar: Nas Media Pustaka, 2021), 43.
} 
Untuk mengajar sesuai dengan kemampuan dan kemampuan peserta ddik, seorang guru perlu mengadopsi komunikasi yang memotivasi peserta didik dalam proses belajarnya. ${ }^{22}$ Komunikasi yang baik dari guru adalah kebutuhan dasar keberhasilan akademik peserta didik, dan kesuksesan keprofesionalan Guru. Guru dengan keterampilan komunikasi yang buruk dapat menyebabkan kegagalan peserta didik untuk belajar dan mempromosikan keberhasilan akademiknya. Peserta didik perlu memahami apa yang benar dan apa yang salah sementara itu sepenuhnya tergantung pada keterampilan komunikasi guru di kelas. ${ }^{23}$ Komunikasi yang baik meminimalkan potensi perasaan tidak baik selama proses pengajaran, untuk itu, agar guru berkomunikasi dengan jelas dan dapat dimengerti oleh peserta didik. ${ }^{24}$

Di samping itu, lingkungan yang baik sangat penting untuk menopang potensi lahiriah peserta didik, termasuk di antaranya adalah lingkungan kelas. Oleh karena itu pengelolaan lingkungan kelas sangat urgen dilakukan oleh pendidik. Secara general manajemen kelas adalah suatu upaya memfasilitasi bagi bermacam macam aktivitas pembelajaran siswa dalam lingkungan social, emotional, dan intellectual dalam kelas. Ketersediaan fasilitas sebagaimana hal tersebut di atas dapat mempengaruhi siwa belajar dan bekerja, terciptanya kepuasan sosial, disiplin diri, perkembangan kognitif, afektif dan psikomotorik serta apresiasi pada diri anak didik. Aktivitas pembelajaran yang efektif dan efisien dalam rangka membentuk peserta didik secara aktif bekerja dan mengembangkan potensi dirinya dengan runut dan tertib merupakan tujuan dari pengelolaan kelas. Menurut Suharsimi Arikunto tujuan pengelolaan lingkungan belajar yang berupa kelas adalah menjadikan setiap anak yang berada di dalam kelas dapat bekerja (berpikir, berinteraksi dan berpendapat) sehingga akan tercapai tujuan pengajaran secara efektif dan efisien. ${ }^{25}$

Pengelolaan kelas juga bertujuan untuk menciptakan suasana pembelajaran yang berbingkai interaksi komunikatif. Artinya, ketika aktivitas pembelajaran berlangsung, seorang guru diwajibkan mampu mengkonfigurasi segala kondisi apapun yang terjadi di dalam kelas supaya

23 Rusman, Pembelajaran Berbasis Teknologi Informasi Dan Komunikasi (Jakarta: Raja Grafindo Persada, 2012), 58. terbentuk two ways communication, yakni komunikasi dua arah antara guru dengan murid, murid dengan guru. Melalui two ways communication diharapkan proses belajar-mengajar dapat berlangsung dengan baik. Hal ini bertujuan untuk memudahkan sekaligus meringankan tugas guru atau wali kelas.

Efektivitas mengajar tidak tergantung pada teknis tetapi pada metode yang diadopsi oleh Guru saat mengajar kepada peserta didik. Guru membutuhkan komunikasi yang jelas untuk pemahaman peserta didik yang baik dan menghindari masalah bagi peserta didik saat belajar serta guru juga perlu memahami dirinya terlebih dahulu sebelum mengajar kepada peserta didik.

\section{SIMPULAN}

Untuk menjadi Guru yang efektif dalam Pendidikan Agama Islam diperlukan empat komponen yakni pertama Guru memiliki penguasaan pengetahuan tentang materi ajar dan bahan ajar yang diajarkan Kedua Guru memiliki kemampuan berpikir kritis dan mampu memecahkan permasalahan yang ada dalam pembelajaran Ketiga Guru memiliki kemampuan pengetahuan tentang karakteristik peserta didik dan menguasai metode pembelajaran. Dan keempat Guru memiliki keterampilan dalam pengajaran serta dapat berkomunikasi baik dengan peserta didik.

\section{DAFTAR RUJUKAN}

Andi Syukri Syamsuri. Pendidikan Guru Dan Pembelajaran. Makassar: Nas Media Pustaka, 2021.

Arief Sadiman. Pendayagunaan Teknologi Informasi dan Komunikasi untuk Pembelajaran. Jakarta: Raja Grafindo, 2004.

Chomsin S Widodo and Jasmadi. Panduan Menyusun Baban Ajar Berbasis Kompetensi. Jakarta: Elex Media Komputindo, 2008.

Depdiknas. Kurikulum 2004 Standar Kompetensi Pendidikan Agama Islam Sekolah Menengah Atas dan Madrasah Aliyah. Jakarta: Pusat Kurikulum Balitbang Depdiknas, 2004.

Djuwairiyah and Moh. Nawafil. "Urgensi Pengelolaan Kelas; Suatu Analisis Filosofis Dan Pemahaman Dasar Bagi Kalangan

24 Rusman, Model-Model Pembelajaran Mengembangkan Profesionalisme Guru (Jakarta: Rajagrafindo Persada, 2013), 16. 25 Suharsimi A., Dasar-Dasar Supervisi Pendidikan, Jakarta: Rineka Cipta, 2004), 53. 
Pendidik Di Pesantren," Edupedia: Jurnal

Studi Pendidikan Dan Pedagogi Islam 5, no. 2 (2021)..

E. Mulyasa. Menjadi Guru Profesional, Menciptakan PembelajaranKreatif dan Menyenangkan. Bandung: Remaja Rosda Karya, 2007.

Elaine B. Johnson. Contextual Teaching and Learning. California: Corwin Press, 2002.

Elliot, S. N., Kratochwill, T.R, Littlefield, J., \& Travers, J.F. Educational Psychology Effective Teaching Effective Learning. Singapore: McGraw Hill Book, 1999.

H.A.R. Tilaar. Pedagogik Teoritis Untuk Indonesia. Jakarta: Kompas, 2015.

Hamzah B. Uno dan Nurdin Mohamad. Belajar 2011 dengan Pendekatan Pailkem: Pembelajaran Aktif, Inovatif, Lingkungan, Kreatif, Efektif, Menarik. Jakarta: Bumi Aksara, t.t.

K.T. Henson dan B.E. Eller. Educational Psychology for Effective Teaching. Belmont: Wadsworth Publishing Company, 1999.

Kementerian Pendidikan Nasional RI. Panduan Guru Mata Pelajaran Pendidikan Agama Islam: Pendidkan Karakter Terintegrasi Dalam Pemeblajaran Di Sekolah Menengah Pertama. Jakarta: Kemendiknas, 2010.

Meriyati. Memahami Karakteristik Peserta Didik. Lampung: IAIN Raden Intan Lampung Press, 2015.

Moh. Nawafil and Junaidi Junaidi. "Revitalisasi Paradigma Baru Dunia Pembelajaran Yang Membebaskan," Jurnal Pendidikan Islam Indonesia 4, no. 2 (April 15, 2020): 215-25, doi:10.35316/jpii.v4i2.193.

Nana Sudjana. Penilaian Hasil Proses Belajar Mengajar. Bandung: Rosda Karya, 2009.

Poerwadarminta. Kamus Umum Bahasa Indonesia. Jakarta: Balai Pustaka, 1979.

R.E Slavin. Educational Psychology: Theory and Practices. New Jersey: Pearson, 2009.

Rusman. Pembelajaran Berbasis Teknologi Informasi Dan Komunikasi. Jakarta: Raja Grafindo Persada, 2012.

Suharsimi A. Dasar-Dasar Supervisi Pendidikan. Jakarta: Rineka Cipta, 2004. 